\title{
Criminologie
}

\section{Erratum : Effet pervers de certaines luttes féministes sur le contrôle social}

\section{Laureen Snider}

Volume 25, numéro 2, 1992

Nouvelles connaissances et nouvelles questions en criminologie

URI : https://id.erudit.org/iderudit/017422ar

DOI : https://doi.org/10.7202/017422ar

Aller au sommaire du numéro

Éditeur(s)

Les Presses de l'Université de Montréal

ISSN

0316-0041 (imprimé)

1492-1367 (numérique)

Découvrir la revue

Citer ce document

Snider, L. (1992). Erratum : Effet pervers de certaines luttes féministes sur le contrôle social. Criminologie, 25(2), 155-160. https://doi.org/10.7202/017422ar d'utilisation que vous pouvez consulter en ligne.

https://apropos.erudit.org/fr/usagers/politique-dutilisation/ 


\section{ERRATUM}

La bibliographie qui devait accompagner cet article paru dans le dernier numéro de CRIMINOLOGIE (volume XXV, numéro 1) a été omise par erreur. Nous prions l'auteure et les lecteurs de nous en excuser.

\section{BIBLIOGRAPHIE}

BACKHOUSE, C. (1985), « $19^{\text {th }}$ Century Canadian Prostitution Law : Reflection of a Discriminatory Society ", Social History, vol. 387, p. 390-393.

BERGER, R., SEARLES, P. et NEUMAN, W. L. (1988), "The Dimensions of Rape Reform Legislation ${ }^{2}$, Law and Society Review, vol. $22, n^{\circ} 2$, p. 329-357.

BLAND, L. (1985), «In the Name of Protection: The Policing of Women in the First World War", in J. Brophy et C. Smart, Women in Law, Boston, Routledge and Kegan Paul, p. 23-49.

BRICKEY, S. et COMAK, E. (1987), «The role of Law in Social Transformation: Is a Jurisprudence of Insurgency Possible?*, Canadian Journal of Law and Society, p. $97-120$.

BRoOKBANK, C. (1982), Sexual Assault: Proposed Canadian Law 1981 - Preliminary Findings, Draft Report to the Federal Department of Justice, Ottawa, February,

BROWNMILLER, S. (1975), Against Our Will: Men, Women and Rape, New York, Simon \& Schuster.

BURSTYN, V. (1985), «Political Precedents and Moral Crusades: Women, Sex and the State », in V. Burstyn, (ed.), Women Against Censorship, Vancouver, Douglas and McIntyre, p. 4-32.

CANADA (1978), Statistiques de la criminalite/Statistics of Crime and Other Offences - 1973. Ottawa, Statistics Canada.

CANADA (1982), Minutes of Proceedings and Evidence of the Standing Commintee on Justice and Legal Affairs Respecting Bill C-53, Ottawa, House of Commons, Issues $\mathbf{n}^{\circ} 77$ to 106.

CANADA, SOLICITOR GENERAL (1984), Bulletin on Reported and Unreported Crimes, Canadian Urban Victimization Survey, p. 1-4. 
CANADA, DEPARTMENT OF JUSTICE (1985), Sexual Assault Legislation in Canada: An Evaluation, Reports 1 and 2. Ottawa, Policy, Programs and Research Branch, Department of Justice, July.

CARINGELLA-MACDONALD, S. (1987), « Marxist and Feminist Interpretations on the Aftermath of Rape Reforms $*$, Contemporaty Crises, vol. 12, $\mathrm{n}^{\circ} 4$.

CHAMBERS, G. et MILlAR, A. (1987), * Proving Sexual Assault», in P. Carlen et A. Worrall (éds.), Gender Crime and Justice, Milton Keynes, Open University.

CHAN, J. et ERICSON, R. V. (1981), Decarceration and the Economy of Penal Reform, Research Report, Centre of Criminology, University of Toronto.

CHAPPELL, D. et SINGER, S. (1977), «Rape in New York City", in Chappell and Signer (éds.), Forcible Rape, New York, Columbia University Press.

CHESNEY-LIND, M. (1987), «Female Offenderts: Paternalism Re-examined», in L. Crites et W. Hepperle (éds.), Women, the Courts and Equality, Newbury Park, Sage, p. 115-139.

CHESNEY-LIND, M. (1988), «Girls and Status Offences: Is Juvenile Justice Still Sexist?", Criminal Justice Abstracts, vol. 20, $\mathrm{n}^{\circ}$ 1, March, p. 144-165.

CHUNN, D. E. (1988), Boys Will Be Men, Girls Will Be Mothers: The Legal Regulation of Childhood in Toronto and Vancouver, 1920-1945, Paper presented at Canadian Sociology and Anthropology Meetings, Windsor, June 1-4.

CLARK, L. et LEWIS, D. (1977), Rape: The Price of Coercive Sexuality, Toronto, The Women's Press.

COHEN, S. (1979), *The Punitive City: Notes on the Dispersal of Social Control *, Contemporary Crises, Amsterdam, Elsevier Publishing Co., vol. 3, p. 339-363.

COHEN, S. (1985), Visions of Social Control, Oxford, Basil Blackwell, Polity Press.

DALY, K. et CHESNEY-LIND, M. (1988), «Feminism and Criminology», Justice Quarterly, vol. 5, $n^{\circ} 4$, October.

DAL,Y, K. (1987), «Structure and Practice of Familial-Based Justice in a Criminal Court », Law and Society Review, vol. 21, n 2, p. 268-289.

DOBASH, R. E., et DOBASH, R. (1975), Violence Against Wives: A Case Against the Patriarchy, New York, Free Press.

DUNFORD, F., HUIZINGA D. et ELLIOTT, D. (1990), «The role of Artest in Domestic Assault: The Omaha Police Experiment», Criminology, vol. 28, $\mathrm{n}^{\circ} 2$, May, p. 183-206.

DUTTON, D. (1984), The Criminal Justice System's Response to Wife Assault, Ottawa, Programs Branch User Report \#26, Ministry of the Solicitor General, Secretariat.

EDWARDS, S. (1987), "Prostitutes, Victims of Law, Social Policy and Organized Crime» in P. Carlen et A. Worrell, Gender, Crime and Justice, Philadelphia, Open University Press, p. 43-57. 
EKLAND-OLSON, S. et MARTIN, S. (1988), «Organizational Compliance With Court Ordered Reform *, Law and Society Review, vol. 22, n², p. 359-383.

ERICSON, R. (1987), «The State and Criminal Justice Reform *, State Control : Criminal Justice Politics in Canada, Vancouver, University of British Columbia Press, p. 21-38.

ERICSON, R. et BARANEK, P. M. (1982), The Ordering of Justice: A Study of Accused Persons as Dependants in the Criminal Process, Toronto, University of Toronto Press.

FRIEDENBERG, E. (1975), The Disposal of Liberty and Other Industrial Wastes, New York, Doubleday.

FUDGE, J. (1990), «What Do We Mean By Law and Social Transformation?», Canadian Journal of Law and Society, vol. 5, p. 47-69.

GREENWOOD, V. et YOUNG, J. (1980), «Ghettos of Freedom: An Examination of Permissiveness, National Deviancy Conference», Permissiveness and Control, New York, Barnes \& Noble.

HAGAN, J., SIMPSON, J. et GILLIS, A. R. (1988), « Feminist Scholarship, Relational and Instrumental Control, a Power Control Theory of Gender and Delinquency *, British Journal of Sociology, vol. 39, $\mathrm{n}^{\circ}$ 3, Sept., p. 301-336.

HALL, S. (1980), Drifting Into a Law and Order Society, London, The Cobden Trust.

HANDLER, J. (1978), Social Movements and the Legal System: A Theory of Law Reform and social Change, New York, Academic Press.

HENRY, S. (1991), «The Post-Modern Perspective in Criminology », in B. MacLean et D. Milovanovic (éds.), New directions in Critical Criminology, Vancouver, Collective Press, p. 71-78.

HENRY, S. et MILOVANOVIC, D. (1991), «Constitutive Criminology: The Maturation of Critical Theory», Criminology, vol. 29, $n^{\circ} 2$, May, p. 293-315.

HUNT, A. (1991), "Postmodernism and Critical Criminology", in B. MacLean et D. Milovanovic (eds.), New Directions in Critical Criminology, Vancouver, Collective Press, p. 79-86.

LEA, J. et YOUNG, J. (1984), What Is To Be Done About Law and Order, Harmondsworth, Middlesex, Penguin.

LOH, N. (1980), «The Impact of Common Law and Reform Rape Statutes on Prosecution: An Empirical Study ", University of Washington Law Review, vol. 55, p. 543-655.

LOH, N. (1981), «Q: What Has Reform of Rape Legislation Wrought? A : A Truth in Criminal Labelling», Journal of Social Sciences, vol. 37, p. 28-52.

MACDONALD, D. (1982a), Sexual Offences - A Comparative Study of The Present Law, Bill C-127 and The Report of the Law Reform Commission, Ottawa, Law and Government Division, Research Branch, Library of Parliament, Sept. 20. 
MACDONALD, D. (1982b), The Doctrine of Recent Complaint, Ottawa, Law and Government Division, Research Branch, Library of Parliament, March 8.

MACDONALD, D. (1982c), The Evolution of Bill C-127, Ottawa, Law and Government Division, Research Branch, Library of Parliament, Sept. 14.

MACLEOD, L. (1980), Wife Battering in Canada: The Vicious Cycle, Ottawa, Ministry of Supply and Services, January.

MARSH, J., GEIST, A. et CAPLAN, N. (1982), Rape and the Limits of Law Reform, Boston, Auburn House.

MCBARNET, D. (1981), Conviction and Law, the State and the Construction of Justice, London, MacMillan.

MCKINNON, C. (1983), «Feminism, Marxism, Method and the State: An Agenda for Theory, Signs», vol. $7, \mathrm{n}^{\circ} 3$, p. 644-645.

MEDEA, A. et THOMPSON, K. (1974), Against Rape, New York: Farrar, Straus and Giroux.

MILOVANOVIC, D. (1991), «Critical Criminology and the Challenge of Post Modernism», in B. MacLean et D. Milovanovic (éds.), New Directions in Critical Criminology, Vancouver, Collective Press, p. 87-94.

MORGAN, P. (1981), «From battered Wife to Program Client: The States's Shaping of Social Problems », Kapitalistate, vol. 9, p. 17-41.

MUSHENO et SEELEY (1986), «Prostitution Policy and the Women's Movement». Contemporary Crises, vol. 10, p. 237-255.

NEUFELD, S. et BOGAARD, B. V. (1977), Characteristics of Rape, Vancouver, Vancouver Rape Relief.

ONTARIO, LEGISLATIVE ASSEMBLY (1982), First Report on Family Violence: Wife Battering, Toronto, Standing Committee on Social Development, Sept.

PATTERSON, E. J. (1979), «How the Legal System Respond to Battered Women», in E. M. Moore (éd.), Battered Women, Beverly Hills, Sage.

PLATT, A. (1969), The Child Savers: The Invention of Delinquency, Chicago, University of Chicago Press.

POLAN, D. (1982), «Toward a Theory of Law and Patriarchy», in D. Kairy (éd.), The Politics of Law, New York, Pantheon.

RAFTER, N. H. (1983), "Chastizing the Unchaste: Social Control Functions of a Women's Reformatory, 1894-1931», in S. Cohen et A. Scull (éds.), Social Control and the State, Oxford, Martin Robertson.

RAFTER, N. (1985), Partial Justice, Boston, Northeastern University Press.

RIFKIN, J. (1982), « Toward a Theory of Law and Patriarchy», in Bierne et R. Quinney (éds.), Marxism and Law, New York, Wiley.

ROBERTS, J. (1991), Sexual Assault Legislation in Canada: An Evaluation. Report $\mathrm{n}^{\circ} 4$, Canada, Department of Justice, Minister of Supply and Services. 
ROOKE, P. et SCHNELL, R. L. (1983), Discarding the Asylum: From Child Rescue to the Welfare State in English-Canada, 1800-1950, Lanham, Md, University Press of America.

ROSEN, R. (1982), The Lost Sisterhood: Prostitution in America, 1900-1918, Baltimore, Johns Hopkins University Press.

ROTHMAN, D. (1971), The Discovery of the Asylum, Toronto, Little Brown.

ROTHMAN, D. (1980), Conscience and Convenience: The Asylum and its Alternatives in Progessive America, Boston, Little Brown.

RUSSEL, D. (1975), The Politics of Rape: The victim's Perspective, New York, Stein and Day.

RUTMAN, L. (1987), «T. J. Kelson and the Development of Child Welfare», in A. Moscovitch, J. Albert (éds.), The Benevolent State, Toronto, Garamond Press, p. 68-77.

SARAT, A. (1985), «Legal Effectiveness and Social Studies of Law: On the Unfortunate Persistence of a Legal Tradition», Legal Studies Forum, vol. 9, p. 23.

SCULL, A. (1977), Decarceration, New Jersey, Prentice-Hall.

SCULL, A. (1981), «Progressive Dreams, Progressive Nightmares: Social Control in $20^{\text {th }}$ Century America», Standford Law Review, vol. 33, p. 301-316.

SHERMANN, L. W. et BERK, R. A. (1984), «The Specific Deterrent Effects of Arrest for Domestic Violence», American Sociological Review, vol. 49, $\mathrm{n}^{\circ} 2$, p. 261272.

SILBERMAN, C. E. (1980), Criminal Violence, Criminal Justice, New York, Vintage Books.

SILBEY, S. (1985), «Ideals and Practice in the Study of Law», Legal Studies Forum, vol. 9 , p. 7.

SILBEY, S. et SARAT, A. (1987), "Critical Traditions in Law and Society Research», Law and Society Review, vol. 21, $\mathrm{n}^{\circ}$ 1, p. 165-175.

SMART, C. (1989), Feminism and the Power of Law, London, Routledge.

SNIDER, D. L. (1985), «Legal Reform and Social Control: The Dangers of Abolishing Rape», International Journal of the Sociology of Law, p. 13.

SNIDER, D. L. (1986), «Legal Aid Reform and the Welfare State», Crime and Social Justice, vol. 24, p. 210-242.

STATISTICS CANADA (1982), Uniform Crime Reporting Statistics on Sexual Offences - Canada and the Provinces 1976-1980, Ottawa, Canadian Centre for Justice Statistics.

STRONG-BOAG, V. (1986), "Wages for Housework: Mothers' Allowances and the Beginnings of Social Security in Canada ", in S. Brickey et E. Comak (éds.), The Social Basis of Law, Toronto, Garamond Press, p. 91-106. 
SUMMER, C. (1981), "The Rule of Law and Civil Rights in Contemporary Marxist Theory», Kapitalistate, vol. 9, p. 63-91.

URSEL, J. (1986), «The State and the Maintenance of Patriarchy: A Case Study of Family, Labour and Welfare Legislation in Canada », in J. Dickinson et B. Russell (éds.), Family, Economy and State, Toronto, Garamond Press, p. 150-191.

WALKER, S. (1985), Sense and Nonsense About Crime, Mentery, California, Brooks/Cole.

WALKOWITZ, J. (1980), Prostitution and Victorian Society: Women, Class and the State, Cambridge, Cambridge University Press. 